\title{
Die Calvinistiese Sondagbeskouing met spesiale verwysing na Sondagsport en die uitsending daarvan
}

\author{
D J Smith
}

Pretoria

\begin{abstract}
The Calvinistic view of Sunday with reference to sport on Sunday and the broadcasting of it

The purpose of this article is to trace the original Reformed view of Sunday on the basis of Calvin's exposition of the Fourth Commandment, and to formulate certain guidelines concerning sport on Sunday and its broadcasting, which conflicts with this view. The Reformed view of Sunday wants to strike a balance between the two extremes of the Pharisaic-legalistic view of Sunday on the one hand, and the libertine freedom and conformity to the world on the other hand. In view of this, the set of directives used to rate sport on Sundays and its broadcasting must be the same as those used to rate any other activity on Sunday.
\end{abstract}

Dit is vir my 'n voorreg om hierdie artikel op te dra aan 'n kollega en vriend, prof dr P J T Koekemoer. Hy het gedurende sy hele loopbaan 'n lewendige belangstelling in die Christelike etiek gehad, daarom het ek dit gepas geag om hom te huldig met 'n artikel op dié vakgebied.

\section{INLEIDEND}

Om vanuit die huidige situasie aan te dui wat die Reformatoriese Sondagbeskouing is, is nie ' $n$ eenvoudige taak nie omdat daar in die loop van die geskiedenis sedert die Reformasie allerlei klemverskuiwings gekom het. Ook hier te lande vind ons, selfs in die geledere van die drie Afrikaanse kerke van reformatoriese erfenis, klemverskille wat die beskouing van die Sondag betref. Om die oorspronklike Calvinistiese standpunt oor die saak te kry, moet 'n mens teruggaan na Calvyn self 
soos hy hierdie saak in sy Institusie en sy Kategismus uiteensit. Die verklaring van die Heidelbergse Kategismus van die inhoud van die vierde gebod behoort ook in gedagte gehou te word om die neerslag van Calvyn se gedagtes in Calvinistiese kringe te peil.

Calvyn is van mening dat die hoofinhoud van die vierde gebod in drie punte saamgevat kan word, naamlik:

- Dat ons ons hele lewe lank 'n voortdurende rus van ons eie werke beoefen sodat die Here daardeur deur sy Gees in ons kan werk. In sy Kategismus sé hy kort en kragtig dat die gebod gegee is om geestelike rus voor te stel.

- Die gebod roep elke mens afsonderlik op om so dikwels as wat hy tyd het, homself te oefen in 'n vrome erkenning van God se werk. Hierdie oefening in ' $n$ vrome erkenning van God se werk kan egter nie alleen op ' $n$ willekeurige los en vas basis geskied nie, daarom koppel Calvyn dit ook aan die wettige orde of gesag van die kerk. Die gebod vra dus tegelyk ook van ons 'n erkenning van die gesag van die kerk om 'n ordereëling te tref om die oefening in 'n vrome erkenning van God se werke op 'n ordelike wyse te reël waar almal op vaste tye die Woord kan hoor, die sakramente kan gebruik wat bedien word en openbare gebede kan doen.

- Die gebod roep ons ook op om mense wat aan ons ondergesik is, nie onmenslik met werk te oorlaai nie. In sy Kategismus se Calvyn kortliks: '...om verligting aan slawe te gee'. Daar is dus, volgens Calvyn, ook 'n menslikheids- of humanitère oorweging agter die instel van die gebod. Dit is dus nie net alleen die aspek van geestelike rus wat na vore kom nie, maar ook die aspek van fisiese rus.

Calvyn se uitleg van die vierde gebod en dus ook sy Sondagbeskouing draai om die drie punte (Calvyn 1559:II, VIII, 34; Calvyn 1545:172). Calvyn (1559:II, VIII, 28) vat die bedoeling van die gebod ook met 'n ietwat ander woordkeuse saam as hy se dat die bedoeling van die gebod is dat ons ons eie gesindhede en werke afsterf, dat ons die dinge van God se koninkryk bedink, en dat ons onsself in die oordenking oefen deur die middele wat God ingestel het. Wat Calyyn hier in gedagte het, is die geestelike rus van ons eie werke, die oordenking van God se werke wat dié rus moontlik maak, en die gebruik van die Woordverkondiging, Nagmaalsbediening en openbare gebed op vasgestelde tye. 


\section{SKADU EN SEREMONIE IN DIE SABBATSGEBOD}

Calvyn beskou die Sabbatsgebod as 'n besondere gebod wat van die ander gebooie te onderskei is. Die onderskeidende kenmerk van die gebod le dan daarin dat hy dit beskou as 'n 'skaduagtige gebod' omdat dit die uitwendige onderhouding van die gebod bevat, wat met Christus se koms afgeskaf is (Calvyn 1559:II, VIII, 28). Met die term 'skaduagtig' het Calvyn die gebruik van die beeld: skadubeeld teenoor werklikheid en vervulling wat ons veral in die Hebreërbrief vind, in gedagte (vgl Heb 10:1). Die gebod is dus skaduagtig omdat dit heenwys na Christus, en ook 'n aspek bevat wat in Christus vervul is en dus nie meer ter sake is nie. Hierdie aspek is die Sabbatsaspek.

Calvyn maak ook gebruik van die onderskeid moreel en seremoniëel. Hy werk met die gedagte dat daar in die Ou Testament sekere sake is wat 'n seremoniële aspek het wat in die Nuwe Testament verval, maar wat ook 'n morele aspek het wat nog steeds in die Nuwe Testament geld. Die vierde gebod is volgens Calvyn so 'n gebod, en dit is vir hom sonder twyfel duidelik dat alles wat seremoniëel is aan die gebod met die koms van Christus afgeskaf is. Die koms van Christus is die spil waarom alles draai want $\mathrm{Hy}$ is die waarheid deur wie se teenwoordigheid alle 'figure' verdwyn, die liggaam, waarvan die aanskouing alle skaduwees laat verdwyn (Calvyn 1559:II, VII, 31; Calvyn 1545:169, 182).

Die instelling van die Sondag in die plek van die Sabbat word deur Calvyn geregverdig vanuit die afskaffing van die skadubeelde en seremonies van die $\mathrm{Ou}$ Testament aan die een kant, maar aan die ander kant tegelyk in die vervulling daarvan in Christus. Die ware rus waarvan die Sabbat 'n afskaduwing was, is in die opstanding van Christus vervul en daarom is die opstandingsdag van die Here (d $\mathrm{i}$ die Sondag) juis uitnemend geskik om Christene daaraan te herinner dat hulle nie meer aan skaduagtige seremonies gebind moet bly nie (Calvyn 1559:II, VII, 34). Calvyn motiveer dus ook die viering van die Sondag in die plek van die Sabbat vanuit die opstanding van Christus en die vervulling van die ware betekenis daarvan in Christus.

Calvyn het ook 'n pragmatiese en ordelikheidsoorweging in sy motivering van die viering van die Sondag in plaas van die Sabbat. Die viering van die Sondag het 'n nuttige doel gedien om die bygeloof en seremonieverknogtheid van die Jode omver te werp. Aan die ander kant het die orde en vrede in die kerk dit wel ook nodig gemaak om 'n dag vir gebruik van die diens van die Here af te sonder.

Calvyn se insigte in verband met die oorgang van die Sabbat na die Sondag, is die insigte wat as die eg reformatoriese behoue gebly het. Haitjema (1961:249) se in sy verklaring van die Heidelbergse Kategismus dat die goeie reg van die Christelike kerk om hom van die Sabbatsgebod los te maak, en in plaas van die sewende dag 
die eerste dag van die week, die Sondag, as die dag van die Here, dit wil sề as die dag van Christus se opstanding te vier en as rusdag te onderhou, kan slegs sinvol verdedig word as 'n mens aanvaar dat die Sabbatsgebod, naas 'n sogenaamde 'morele' gedeelte, ook 'n 'seremoniële' gedeelte het wat met Christus se koms weggeneem word.

Ons kan dus nie in 'n reformatoriese Sondagbeskouing die Sondag sonder meer aan die Sabbat gelyk stel nie en al die wette van die Sabbat net so op die Sondag oordra of selfs van 'n wettiese benadering tot die Sondag uitgaan nie.

\section{GEESTELJKE RUS AS HOOFINHOUD VAN DIE SONDAGVIERING}

In Calvyn se beredenering van die vierde gebod word dit duidelik dat hy die geestelike rus as die kernaspek sien wat in die gebod verwoord word. Hy is daarvan oortuig dat die afskaduwing van die geestelike rus in die Sabbat, die vernaamste plek ingeneem het. Hy gaan dus van die gedagte uit dat die Sabbat 'n voorafskaduwing van die geestelike rus verskaf wat die Here ook in die Nuwe Testament van die gelowiges eis op die dag of tyd wat aan sy diens gewy word. Die beklemtoning van die voorrang van die geestelike rus, word deur Calvyn onder andere daaruit afgelei dat God in die Ou Testament van geen ander gebod so 'n streng onderhouding geëis het as juis van hierdie gebod nie. Onder die talle Skrifbewyse wat hy aanhaal om sy saak te staaf, neem Esegiël 20:12 'n belangrike plek in sy beredenering in. Calvyn stel dat die hoofinhoud van hierdie teks daaruit bestaan dat die Sabbat ' $n$ teken is waardeur Israel sou leer dat die Here hulle heiligmaker is. Indien ons heiligmaking sou bestaan in die doodmaak van ons eie wil, sê Calvyn is dit vir hom duidelik dat daar 'n paslike ooreenkoms is tussen die uiterlike saak ( $\mathrm{d} w \mathrm{~s}$ die Sabbatsgebod self met sy eis van rus en nie werk nie) en die inwendige saak (d w s die geestelike rus). Hieruit lei hy dan af dat die geestelike rus ook in die Sondagviering geëis word (Calvyn 1559:II, VIII, 29). Hy onderstreep ook die geestelike rus in sy Kategismus (Calvyn 1545:168): 'Leraar: gebied Hy ons dan om ses dae te werk sodat ons op die sewende dag kan rus? Seun: nie doodeenvoudig dit nie, maar wanneer $\mathrm{Hy}$ ses dae vir die arbeid van die mens toelaat, sonder $\mathrm{Hy}$ die sewende dag uit om dit vir sy rus te bestem.'

Calvyn vul die begrip geestelike rus met 'n baie spesifieke inhoud wat hy kort saamvat (Calvyn 1559:II, VIII, 28, 29) in die gedagte dat die hemelse Wetgewer deur die rus op die sewende dag vir die volk Israel die geestelike rus afgebeeld het waardeur gelowiges van hulle eie werke moet afsien om God in hulle te laat werk. Hierdie geestelike rus vind plaas wanneer 'n mens van jou eie werk rus. Calvyn stel dit in sy Kategismus (Calvyn 1545:173) so: 'Dit is wanneer ons rus van ons beson- 
dere werke sodat God sy werk in ons kan volbring.' Calvyn gee 'n breë betekenis aan die begrip 'rus van ' $n$ mens se eie of besondere werke'. Dit is baie duidelik dat Calvyn beslis nie die klem le op 'n fisiese niksdoen op die Sondag nie. Daarom vind ons ook nie by hom 'n wetties gestyleerde lys van wat mag en nie mag op die Sondag nie. Calvyn gee die begrip hoofsaaklik inhoud vanuit 'n sekere geestesingesteldheid wat in 'n gelowige se hart moet heers. Hy verwoord dit in sy Kategismus (Calvyn 1545:174) so: 'Leraar: wat is die wyse van die rus? Seun: as ons ons vlees kruisig: dit beteken as ons ons eie natuur verloën sodat ons deur die Gees van God geregeer kan word.' Die geestelike rus begin dus by die ingesteldheid en bereidheid om 'n mens se eie ek te kruisig. Hierdie ingesteldheid lei dan daartoe dat 'n mens afstand doen van al ons selfgerigte werke wat ons eie belang dien en daarom bereid is om ons eie wil te laat vaar en alle werke wat uit ons sondige gedagtes en begeertes kom, te laat vaar en op die wyse die geestelike rus te beoefen.

Vanuit 'n gedagtegang wat so opgebou is, lei Calvyn (Calvyn 1559:II, VIII, 29) af dat die Christelike Sondagviering daarin lê dat ons heeltemal moet rus sodat God in ons kan werk, ons moet afstand doen van ons wil, ons hart tot berusting laat kom en van al die begeertes van ons sondige natuur (vlees) afstand doen. Uiteindelik moet ons rus van al die bedrywighede van ons eie verstand, om terwyl God dan in ons aan die werk is, in Hom te rus soos Hebreërs 3:13 en 4:4 leer.

Die geestelike rus loop uiteindelik net op een doel uit en dit is om die geleentheid te skep dat God in die mens kan werk en die mens in God rus kan vind.

Die reformatoriese tradisie het Calvyn volledig gevolg in sy klem op die geestelike rus in die Sondagviering. In die korrekte opvatting van die Sondagviering le die klem nie op wat op die Sondag mag gedoen word en nie gedoen word nie, maar uit en uit op wat gedoen moet word om die geestelike rus in God te verwerklik. Die regte Sondagviering word in die reformatoriese Sondagbeskouing gebou op die positiewe oproep om van al ons eie werke te rus sodat daar 'n geleentheid kan wees dat God in ons werk en ons rus in hom kan vind. Ons moet van al ons sondige werke rus wat uit ons sondige natuur en begeertes kom. Daarom moet ons ook rus van al die werke wat uit ons eie wil, eiebelang en selfgerigtheid kom. Die geestelike rus het altyd 'n positiewe gerigtheid, naamlik God se werk in ons en ons rus in Hom.

Die oproep tot rus raak nie net suiwer en alleen die geestelike vlak van ons lewe nie, maar kring ook wel uit na al die aspekte van ons lewe en ons lewensbedrywighede. Die rus wat op Sondag in ons hele lewe gevra word, kan nie benader word vanuit die standpunt van moet en moenie en geen werk ter wille van die werk self nie. Dit moet benader word vanuit die positiewe doel en gerigtheid van die rus, naamlik om geleentheid te skep vir God se werk in ons. Daarom kan die kerk nie die eis stel dat daar geen arbeid en bedrywighede van enige aard op 'n Sondag sal 
wees nie. Die kerk kan wel van die owerheid sowel as van al sy lidmate vra om vir sover dit moontlik is, werk en ander bedrywighede tot ' $n$ minimum te beperk en na te laat oral waar dit gelowiges verhinder om die geestelike rus te kry en hulle dus ook verhinder om die Here behoorlik op 'n Sondag te dien sodat $\mathrm{Hy}$ in hulle kan werk.

\section{Die Sondag en die volmaakte Sabbatsrus}

Wanneer Calvyn oor die feit praat dat dit spesifiek die sewende dag is wat as rusdag gestel word in die gebod, wil hy nie te veel maak van die getal sewe nie. Tog beskou hy dit nie as onredelik nie om in die eerste plek te aanvaar dat die Here die onderhouding van die gebod wou aanmoedig deur sy eie rus op die sewende dag na die skepping, as 'n voorbeeld voor te hou vir die volk.

In die tweede plek stel Calvyn ook dat as 'n mens 'n verborge betekenis aan die getal sewe wou toeken, 'n mens sou kon sê dat die getal sewe in die Skrif die getal van volmaaktheid is en juis gekies is om die ewigdurendheid van die volmaakte Sabbatsrus aan te dui. Hy aanvaar dat dit 'n waarskynlike betekenis van die getal sewe is dat die Here, juis deur die getal van volmaaktheid te kies, te kenne wil gee dat die Sabbat nooit volkome sal wees totdat die laaste dag gekom het nie. Die gedagte hieragter is, volgens Calvyn, dat ons ons salige rus in God in hierdie lewe op die Sabbat begin, en dat ons in hierdie rus daagliks vordering maak, maar omdat ons 'n voortdurende stryd met ons sondige natuur het, sal hierdie rus nie volmaak wees voordat die Here alles in almal sal wees nie (Calvyn 1559:II, VIII, 30; Calvyn 1545:177, 178).

Calvyn sien die saak dus so dat die Here met die sewende dag (en vir Christene met die geestelike rus op Sondag) vir ons die toekomende volmaaktheid van sy Sabbat op die laaste dag afgeteken het, sodat ons deur die voortdurende oordenking van die Sabbat ons hele lewe lank na die volmaaktheid sal strewe.

Die reformatoriese Sondagbeskouing gaan uit van die gedagte dat die rusdag ook 'n eskatologiese betekenis het. Die rusdag word telkens opnuut gevier as 'n teken wat heenwys na die volmaakte Sabbat wat aanbreek met Christus se wederkoms. Elke Sondag moet gevier word met die besef dat dit ons aanspoor om voortdurend te strewe na die volmaakte geestelike rus terwyl ons nog in hierdie onvolmaakte bedeling is.

\section{DIE SONDAG AS BESONDERE DAG VAN DIE DIENS VAN DIE HERE}

Dit is opvallend watter ruim opvatting Calvyn (en ook Luther) gehad het oor die onderhouding van die rusdag as dag van die feestelike diens van die Here juis op die 
Sondag. Hy het in beginsel onverskillig gestaan teenoor watter dag afgesonder word. Hy was bereid om hom selfs nie eens te bind aan die getal sewe nie. Wat hom betref, kon die kerk enige ander gepaste dag bepaal, solank as wat daar net nie bygeloof was in die onderhouding van die dag nie.

Die geskiedenis het so verloop dat die kerke van die Hervorming nooit werklik enige ernstige aandag gegee het aan hierdie gedagte van Calvyn van die moontlikheid van enige ander dag in plaas van die Sondag nie, met die gevolg dat dit nie beskou kan word as iets eie aan die reformatoriese tradisie nie. Inteendeel, dit sou by haie mense op weerstand stuit, soos byvoorbeeld Van Wyk (1986:56) dit verwoord.

As ons egter die polemiese motief en die Bybelse motief in ag neem wat Calvyn gebruik in die beredering van die saak, dan word dit duidelik dat sy motiewe wel deel van die Reformatoriese erfenis geword het. Aan die een kant het Calvyn gepolemiseer teen Judaïserende tendense wat die Sondagviering betref, waar die Sondag aan die Sabbat gelykgestel is en die Sabbatswette reglynig op die Sondag oorgedra is. Daarom was hy bereid om die binding aan ' $n$ spesifieke dag tot ' $n$ groot mate te relativeer en beskou hy nie die Sondag as heiliger as ander dae nie. Hierdie gedagte is wel in die Reformatoriese tradisie opgeneem, in elk geval in die aanvanklike tradisie.

Aan die ander kant gaan hy ook van die gedagte uit dat ons nie net een dag van ons lewe nie, maar elke dag van ons lewe aan die Here wy. Calvyn (1559:II, VIII, 31) sê dat Christus nie net tevrede is met één dag nie, maar slegs met die ganse loop van ons lewe; totdat ons geheel en al onsself afgesterwe het, en met God se lewe vervul is. Hierdie besef is vir hom ' $n$ belangrike rede waarom die bygelowige onderhouding van spesifieke dae afgeskaf moet wees. In Calvyn (1545:175) se Kategismus word dit soos volg gestel: 'Leraar: Maar is dit genoeg dat dit net elke sewende dag gebeur? Seun: Nee, dit is voortdurend nodig. Want vanaf die stadium waarop ons eenmaal daarmee begin, moet ons daarmee deur ons hele lewe volhou.'

Calvyn se diepste motief is dus dat elke dag van 'n gelowige se lewe op dieselfde wyse as 'n Sondag aan die Here gewy moet word en met die gees van Sondag gevul moet word. Dit is die rede waarom daar vir hom wesenlik geen verskil tussen verskillende dae gemaak kan word nie. Hy het natuurlik ook steeds in gedagte gehad dat die Sabbat afgeskaf is en in Christus vervul is. Ook die gedagte van Calvyn het neerslag gevind in die reformatoriese kerke. Dit is onder andere verwoord die Nederlandse Geloofsbelydenis, artikel 25: Ons glo dat die seremonies en figure van die Wet opgehou het met die koms van Christus en dat aan alle skaduwees 'n einde gekom het sodat die gebruik daarvan onder die Christene afgeskaf moet word; nogtans bly die waarheid en substansie daarvan vir ons en Christus 
bestaan in wie hulle vervul is', en ook in die Heidelbergse Katagismus Sondag 38: 'Ten tweede dat ek al die dae van my lewe my bose werke moet laat staan, die Here deur sy Gees in my laat werk en so die ewige Sabbat in hierdie lewe moet begin.'

Calvyn het egter goed besef dat dit onprakties is om die saak net so oop te los en dit aan die willekeur van mense oor te laat om sommer enige tyd bymekaar te kom om die Here te dien in die erediens, Woordverkondiging, Nagmaal, ensovoort. Calvyn se ideaal was dat die gemeente elke dag moes samekomste hou, maar hy het besef dat dit tot wanorde sou lei, want daar is baie mense wat te swak is om aan sulke eise te voldoen. Aan die ander kant kan 'n mens ook nie vanuit die Christelike liefde sulke veeleisende eise aan mense stel nie. Om hierdie redes kon Calvyn die sinvolheid insien van 'n samekoms op 'n spesifieke dag. Hy grond dan die sinvolheid en bruikbaarheid van die Sondag as rusdag en dag aan die diens van die Here gewy op die orde wat daar volgens 1 Korintiërs 14:40 in die gemeente moet heers. Sonder regering, orde en reëls sou daar net verwarring en verwoesting in die kerk wees, en daarom is die samekoms op die Sondag nie net 'n sinvolle saak nie, maar ook 'n noodsaaklike saak. Die ervaring, dit wil sê die praktyk, wys ook uit dat so 'n reêling nodig is (Calvyn 1559:II, VIII, 32). die viering van die Sondag is dus vir Calvyn 'n ordereëling en 'n praktiese reëling.

Die doel van hierdie ordereëling is dat die gemeente ook die tweede eis wat die Here in hierdie gebod vra, kan nakom. Dit verwoord Calvyn (1545:184) so: 'Leraar: wat bly dan verder vir ons oor na aanleiding van die gebod? Seun: Dat ons nie 'n heilige instelling wat tot die geestelike orde van die kerk bydra, moet verwaarloos nie, maar in besonder dat ons die heilige vergaderings met die oog daarop om die Woord van God aan te hoor, om sy geheimenisse te vier, en vir heilige gebede, moet bywoon soos dit verorden is'. Hy se ook: 'Leraar: Watter orde moet ons dan op die dag nakom? Seun: Dat sy volk byeen moet kom om die leer van Christus aan te hoor, om openbare gebede by te woon en belydenis te doen van hulle geloof (Calvyn 1545:180).

Die tweede saak, naas die rusmotief, waarop dit volgens Calvyn in die vierde gebod neerkom, is dat ons op geordende wyse tyd en geleentheid maak om die Here te dien. Dit vind plaas tydens kerkdienssamekomste waar die verkondiging van God se Woord, die gebruik van die sakramente en die gebed die middelpunt vorm, maar verder ook dat ons in ons persoonlike hoedanigheid op die vasgestelde tyd geleentheid sal maak vir die diens van God.

Wanneer die Heidelbergse Kategismus (vraag en antwoord 103) vra na die inhoud van die vierde gebod, stel dit die motief van die onderhouding en beoefening van die diens van God eerste aan die orde terwyl Calvyn dit tweede aan die orde stel. Die motief wat by Calvyn eerste aan die orde gestel word en as die sentrale 
behandel word, word dan eers hierna aan die orde gestel. DiE werkwyse kan verstaan word vanuit die praktiese gerigtheid van die Kategismus. Die vraag kan egter gestel word of dit nie dalk aan die volgorde van die Heidelbergse Kategismus te danke is dat Calvinistiese kerke die swaartepunt in hulle Sondagbeskouing meer op die Sondag as geleentheid vir kerkdiens, erediens, Nagmaalsviering, doop en gemeentelike samekoms gele het, terwyl die motief van geestelike rus wat by Calvyn 'n prominente plek inneem, meer op die agtergrond'n rol speel nie.

Die Heidelbergse Kategismus bring in elk geval ook nog die gedagte van die Sondag as besondere geleentheid vir die insameling van offergawes vir die barmhartigheidsdiens na vore naas die prediking, sakramentsbediening en diens van die gebed.

Ons reformatoriese erfenis, wat bostaande betref, kan in 'n paar kerngedagtes saamgevat word. Die reformatoriese Sondagopvatting hou ook in dat die Sondag nie as heiliger as ander dae beskou kan word nie. In der waarheid geld die eis van die Sondag vir elke dag van ons lewe, naamlik dat ons ons lewe volkome aan die Here wy en Hom dien soos ons dit in besonder op Sondag moet doen. Elke dag is aan die Here geheilig en moet met die gees van Sondag gevul word.

Hoewel die Sondag nie heiliger as ander dae is nie, is die Sondag tog 'n besondere dag wat vir 'n spesifieke doel afgesonder is. Die Sondag is die dag wat in besonder afgesonder is vir die diens van die Here met die middele wat Hy in besonder daarvoor bestem het: die erediens, die Woordverkondiging, Sakramentsviering, gebed, barmhartigheidsdiens en die afsterf van ons oue mens asook die opneem van die nuwe lewe by God.

Die Sondag is in besonder aan die diens van die Here gewy ter wille van die goeie orde in die gemeente en om gereeld geleenthede te gee om tyd vir die Here af te sonder.

Dit is juis die Sondag wat in besonder aan die Here geheilig (dit wil sê gewy) word omdat dit die dag van Christus se opstanding is, en dit is juis die opstanding wat dit waarlik die dag van die Here maak. As die dag van die opstanding van Christus is dit ook die dag wat 'n einde maak aan die voorlopigheid van die OuTestamentiese Sabbatsrus en aankondig dat die ware geestelike rus in Christus met sy opstanding aangebreek het (vgl Calvyn 1559:II, VIII, 34). Juis die gesigspunt wat Christus se opstanding bied, maak die Sondag uitnemend geskik om dit in besonder aan die diens van die Here te wy.

Die reformatoriese standpunt van 'n wesenlike gelykheid en heiliging van alle dae aan die Here, maar tegelyk ook van die Sondag wat as die dag van die opstanding van die Here tog as ' $n$ besondere dag afgesonder is vir die geestelike rus in God en die diens van die Here, het sekere implikasies. 
Die implikasies is dat ons aan die een kant nie 'n stel afsonderlike etiese reëls kan opstel wat net op die Sondag alleen van toepassing sou wees, maar nie op 'n ander dag ook geldingskrag het nie. So 'n siening van die Sondag bied net 'n groeibodem vir 'n Fariseiese benadering van die Sondag (vgl Da Silva 1966:37).

Aan die ander kant kom die aanvaarding dat die Sondag wel in besonder afgesonder is vir die diens van die Here en ons geestelike nus in sy diens, daarop neer dat die Sondagviering wel sekere etiese eise stel. Dit is egter nie etiese eise wat op hulle eie staan nie, maar hulle vloei voort uit die primére betekenis van die Sondagviering as dag van geestelike rus en dag van besondere diens van die Here (vgl Da Silva 1966:37). Die etiese eise met betrekking tot Sondagviering is dus slegs daarop gemik om geleentheid te skep vir die geestelike nus en diens van die Here en om te sorg dat dit ordelik en sonder hindernis kan gebeur. Die etiese eise van Sondagviering is dus ondergeskik aan die betekenis en inhoud van die Bybelse Sondagviering. Reformatoriese Sondagbeskouing in hierdie verband het 'n ruimer opvatting oor Sondagviering tot gevolg.

In die eerste plek ruimer in die sin dat daar meer van die gees en inhoud van die Sondagviering na die res van die week oorgedra word en daar meer ruimte kom vir byvoorbeeld die gedagte wat Van Wyk (1986:56) so verwoord:

Die kerk moet myns insiens oorweeg om terug te keer na die gebruik van die Vroeë Kerk en die Reformasie, naamlik om gedurende die week (byvoorbeeld op 'n Woensdagaand) eredienste te hou - moontlik as alternatief van die Sondagaanderediens. So 'n gebruik sal ook baie help om weg te beweeg van 'n Sondaggodsdiensmentaliteit en as aansporing dien vir 'n lewe van diens aan God en sy koninkryk 'al die dae van my lewe'.

Aan die ander kant het dit ook tot gevolg dat die Sondag self ook met 'n ruimer opvatting benader word en dat daar plek gemaak word vir 'n gladder en minder wetties-voorskrywende en beperkende inskakeling van die daaglikse gang en bedrywighede van die lewe by ons Sondagviering. Die reformatoriese Sondagbeskouing bied ook ruimte om op die Sondag met sake van die gewone gang van die lewe besig te wees sonder om deur die angsvallige vraag van mag dit of mag dit nie, gekwel te word. Die ruimer opvatting oor die Sondag was aanvanklik gemeengoed by sowel Luther as Calvyn (Søe 1965:383). Die ruimer opvatting is onder andere verwoord in Luther se klein en groot Kategismus se uitleg van die derde gebod en die Confessio Augustana, artikel XXVII, 57vv. Dit is daaruit in die Lutherse tradisie bestendig. 
In die Calvinisme het ons ná Calvyn die opkoms van sekere meer wettiesingestelde opvattings gekry wat in baie kringe Calvyn se ruimere siening oor die Sondag op die agtergrond gedruk het (vgl Soe 1965:383). In Nederland het daar in die sewentiende eeu twee maal 'n Sabbatstryd opgevlam wat verband hou met die vraag in hoeverre die vierde gebod 'n seremoniële gebod is wat in die bedeling van die Nuwe Verbond weggeval het. Die eerste is in die jare 1618-1633 ontketen deur Engels-Puriteinse invloede wat met die sogenaamde Nadere Reformasie uitgeloop het op die afkondiging van streng eise vir die viering van die Sondag en die openbare heiliging daarvan. Die tweede het losgebreek rondom Coccejus se verbondsteologie waarin teen die streng wettiese opvattings in die Sondagheiliging geprotesteer is (Haitjema 1962:251-253).

Hierdie stryd se invloede is ook op ons land oorgedra en daarby kom ook nog die invloed van die Skotse predikante wat in die Kaapse Kerk ingevoer is in die vorige eeu. Beide invloede is merkbaar in die neiging in baie AfrikaansCalvinistiese kringe om die Sondag en die Sabbat nader aan mekaar te trek en 'n meer wettiese interpretasie aan die Sondagviering te gee.

Die reformatoriese Sondagopvatting waak teen altwee die uiterstes wat daar in die Sondagopvatting kan wees, soos Haitjema (1962:253) dit stel. Aan die een kant is daar die uiterste van ' $n$ streng wettiese benadering, en aan die ander kant is daar die geheel en al vrye en ruime benadering. Die een uiterste is nie beter as die ander nie, want by beide word die ewewig van die Christelike verantwoordelike handeling uit balans geruk.

Aan die een kant dreig die gevaar van wettisisme en Fariseïese skynheiligheid met sy lys van wat mag op die Sondag en nie mag nie. Aan die ander kant dreig die gevaar van verwêreldliking van die Sondag en 'n totale aanpassing van ons lewe by die lewe van die wêreld.

Die reformatoriese opvatting dat die Sondag wesenlik gelyk is aan enige dag en aan die Here gewy is, maar tegelyk as opstandingsdag die dag van geestelike rus in en diens aan die Here is, bring die balans tussen wettisisme en 'n libertynse vryheid en wêreldgelykvormigheid met betrekking tot die Sondagviering.

\section{DIE SONDAG EN ARBEIDSRUS}

Calvyn onderskei as derde en laaste motief by die Sabbatsgebod dat dit eis dat slawe, diensknegte, handewerkers en almal wat onder gesag werk, 'n spesifieke dag moet hê om te rus van hulle arbeid. Hy motiveer hierdie stelling vanuit die bewoording van die gebod self wat eis dat geen dienskneg, geen man of vrou wat vir 'n mens werk, ook geen bees of donkie of die vreemdeling wat by iemand woon, op 
die Sabbat sal werk nie. Calvyn onderskei dus ook 'n menslikheidsoorweging in die gebod en dit maak hy ook op die Sondag van toepassing.

Die reformatoriese Sondagbeskouing maak ook plek vir die motief dat 'n mens ook op die Sondag geleentheid moet kry om liggaamlik te rus en 'n geleentheid moet kry om van 'n mens se daaglikse arbeid te rus. Hierdie motief is egter heeltemal ondergeskik aan en gerig op die motiewe van geestelike rus en dien van die Here. Dit mag nie verstaan word as 'n luilekker niksdoen ter wille van die niksdoen self nie. Die rus van ons broodwinnersarbeid word gegee sodat daar geleentheid kan kom om die Here in ons te laat werk.

\section{DIE SONDAG AS FEESDAG}

Die Sondag is ook 'n feesdag en moet as 'n feesdag gevier word, omdat dit die dag van Christus se opstanding uit die dood is; die dag wat bevestig dat Hy ons Verlosser uit sonde en dood is. Dit is 'n feesdag omdat dit die dag is wat ons daaraan herinner dat die volmaakte Sabbatsrus van Hebreërs 4 vir ons aangebreek het, dat ons nou in die rus kan ingaan en dat Christus die rus met sy wederkoms volkome aan ons sal gee.

Dit is 'n feesdag omdat dit die dag is waarop ons in dankbaarheid feestelik as gemeente kan saamkom rondom die Woord, die sakramente, belydenis, gebed, sang en in die gemeenskap as gelowiges.

Die motief van die Sondag of feesdag is myns insiens in die Calvinistiese Sondagbeskouing 'n soort oorkoepelende, samebinde motief ten opsigte van die ander drie hoofmotiewe vir die Sondagviering. Die reformatoriese Sondagbeskouing lê die klem op die positiewe feesviering op die Sondag. Die Sondag moet op so 'n manier gevier word dat dit 'n geleentheid van geloofsblyheid, dankbaarheid en feestelikheid is.

\section{'N ALGEMENE RIGLYN VIR DIE REGTE SONDAGVIERING}

In die reformatoriese Sondagbeskouing kan die Sondag en die Sabbat nie sonder meer gelyk gestel word nie. Die Christelike Sondag is nie gelyk aan die Joodse Sabbat nie. Die Sondag, en die viering van die Sondag, kan gevolglik nie wetties benader word in dié sin dat daar na 'n algehele werkverbod gestreef word asof die heiliging van die Sondag in 'nie werk nie' sou lè. Die klem by die viering van die Sondag le in die eerste plek nie op geen arbeid nie, maar daarop dat dit die dag is wat aan die Here gewy is, en dat ons ons arbeid so moet inrig en inperk dat ons in staat kan wees om die Here na behore te dien. Die klem lê dus daarop dat ons van 
ons eie werke moet rus om des te beter in staat gestel te word om die Sondag aan die diens van die Here te wy.

As algemene riglyn kan gestel word dat die kerk hom daarvoor moet beywer dat die arbeids-, sake-, sport- en ontspanningsbedrywighede op 'n Sondag sover as moontlik beperk moet word om elke gelowige in staat te stel om ongehinderd saam met die gemeente in die erediens en gemeentesamekoms in diens van God te vergader. Alle aktiwiteite moet so ingerig word dat so min moontlik mense verhinder word om deel te hê aan die erediens. Die Christelike opvatting van Sondagviering is: rus van ons eie werke ter wille van die diens van God en nie ter wille van die werke self nie. 'n Opvatting van rus van ons arbeid ter wille van die rus van die arbeid self dien nie 'n regte Sondagviering nie, maar 'n Fariseïese wettisisme.

\section{SONDAGSPORT EN 'N VERBOD DEUR DIE OWERHEID}

Daar is in die verlede al die beroep op die owerheid gedoen om openbare georganiseerde sport op Sondae te verbied. Dit is egter duidelik dat dit nie 'n saak is waaroor op 'n oorvereenvoudigde manier geredeneer kan word nie (vir 'n algemene oriëntering oor die saak van sport en Sondagsport, kyk Douma 1981 en Heyns 1986:401vv).

In die eerste plek sal daar helderheid moet wees oor wat onder openbaar en georganiseerd verstaan word, en ook oor watter openbare georganiseerde sportaangeleenthede die owerheid regsbevoegdheid het. 'n Mens kan probeer om uit te gaan van die onderskeid tussen georganiseerde sport en spontane spel (Van Wyk 1986:58), om te onderskei watter sportgeleenthede deur die owerheid verbied kan word, maar die onderskeiding werk nie bevredigend nie omdat dit nie werklik die sportbedrywighede van privaatklubs en privaatindividue insluit nie. Om te bepaal wat openbaar en georganiseerd is, kan 'n mens twee kriteria aanle: eerstens moet dit 'n geleentheid wees waar daar gebruik gemaak word van openbare geriewe in besit van die sentrale owerheid of van owerhede op tweede en derde vlak; tweedens moet daar by sodanige geleenthede toegangsgeld gevra word (in die geval kan dit ook op privaateiendom wees). Dit is in werklikheid al sportaangeleenthede op Sondae waaroor die owerheid in die normale gang van sake beheer behoort uit te oefen.

Die owerheid mag nie sommer ingryp in sport- en ontspanningsbedrywighede van private individue nie, hetsy waar dit enersyds in private klubs of vrywillige groepe georganiseer word, hetsy waar dit andersyds beoefen word in invividuele hoedanigheid. Die enigste uitsondering is waar sodanige sportbeoefening van individue of privaatklubs steurend inwerk op die reg van ander mense om vry en 
ongehinderd op Sondag hulle godsdiens te beoefen of ook hulle reg tot rus en rustigheid op 'n Sondag.

In terme van deelnemertal en toeskouertal kom daar veral drie sportaangeleenthede ter sprake as ons oor openbare georganiseerde sport praat, naamlik krieket, sokker en ook die reëlings van groot sake-ondernemings (soos byvoorbeeld mynmaatskappye) wat baie van hulle, veral gekleurde, werknemers net op Sondae geleentheid gee om hulle sport- en ontspanningsbedrywighede te beoefen. Gholf kan dalk ook by die lys ingesluit word. In watter mate kan die owerheid oor hierdie sportbeoefening op Sondag beheer uitoefen en in watter mate behoort die owerheid dit aan bande te le?

Dit is duidelik dat hier baie verskillende oorwegings in ag geneem moet word en dat 'n mens ten minste eers die volgende sake moet oorweeg voordat 'n uitspraak gegee kan word:

- Kan die kriterium van openbaar en georganiseerd werklik toegepas word, of kan die grens van openbaar en georganiseerd soms moeilik aangewys word?

- Sommige sportsoorte, soos sokker en krieket, het 'n lang tradisie van Sondagbeoefening wat ook wel van owerheidsweë toegelaat is, al is dit dan stilswygend. Ingryping en verandering hier kan tot groot ontevredenheid lei.

- Daar moet in ag geneem word dat baie mense se kulturele en lewensbekoulike agtergrond ruimte laat vir die beoefening van Sondagsport. Mense se reg tot gewetensvryheid moet dus ook in ag geneem word.

- Selfs verskillende kerkgroepe en Christene onderling verskil oor hierdie saak. Ons het standpunte wat wissel van die geheel en al vrye siening wat alle sportbeoefening op 'n Sondag sonder gewetensbeswaar aanvaar, tot die streng wettiese opvatting wat byna alle aktiwiteite op 'n Sondag streng wil inperk. 'n Mens sou moeilik net een groep se mening op al die ander kan afdwing.

- Die werksomstandighede van beduidende groepe werkers in sekere bedrywe, soos die mynbedryf, wat sodanig is dat hulle geleentheid tot sportbeoefening grootliks tot 'n Sondag beperk word, is wel 'n moeilike probleem.

- Dit is ook belangrik om te oorweeg of sodanige sportaktiwiteite so plaasvind dat dit die moontlikheid skep om mense van die erediensbywoning en ander godsdienstige handelinge op ' $n$ Sondag weg te hou of in elk geval 'n hindernis of steurnis kan veroorsaak.

- Ons sal moet toegee dat dit moeilik is om 'n maatstaf neer te le wat duidelik en sonder vaaghede in wetgewing omskryf kan word.

- Dit kan nie van die regering verwag word om wette te maak om mense te dwing om Christelik te lewe nie. 
- Dit is wel die regering se taak om in sy wetgewing voorsiening te maak vir godsdiensvryheid en om vir die kerk vryheid te gee vir ongehinderde godsdiensbeoefening.

Die Nederduitsch Hervormde Kerk het in die verlede eenstemmigheid betuig met die aanbeveling van die Tussenkerklike Kommissie soos opgeneem in die Agenda van die 1976 Algemene Kerkvergadering (bl 219): 'dat alle sportbyeenkomste wat georganiseerd en gekommersialiseerd aangebied word op Sondae, verbied word' (Nederduitsch Hervormde Kerk 1976). Ons gaan nie verder in op al die uitsprake van die Kerk in hierdie verband asook die aard van die teologie wat daaragter le nie, aangesien dit nie die bedoeling van hierdie studiestuk is nie. Dit het intussen geblyk dat hierdie aanbeveling nie in die praktyk deur die owerheid na sy volle konsekwensies deurgevoer kon word nie en dat georganiseerde sport op Sondae in der waarheid eerder toegeneem het. Die Kerk behoort nogtans by hierdie standpunt te bly staan, wel nie omrede van 'n wettiese verstaan van die Sondag nie, maar wel om die rede dat daar op die manier duidelik standpunt ingeneem word teen 'n toenemende verwêreldliking van die Sondag. Hierdie standpunt moet so verstaan word dat dit nie sonder meer deelname aan Sondagsport tot sonde verklaar nie, maar wel wil beklemtoon hoe belangrik dit is om ons Sondagbedrywighede so in te rig dat ons die Sondag voluit aan die Here kan wy en volle geleentheid kan kry om Hom op dié dag op die regte manier te dien.

\section{SPORTUITSENDINGS OP 'N SONDAG}

In 'n beoordeling van die saak van sportuitsendings op 'n Sondag oor die radio en televisie, moet al die oorwegings wat by die standpuntinname oor georganiseerde sport op 'n Sondag ter sprake gekom het, ook weer in ag geneem word. Daarby geld ook nog die volgende oorwegings:

- Die feitelikheid van radio- en televisie-uitsendings op 'n Sondag moet aanvaar word.

- Die Kerk kan nie van 'n openbare instansie soos die SAUK verwag om in sy uitsendings op Sondag die feit van sportgebeure op 'n Sondag te verswyg asof dit nie bestaan nie. Dit sou volstruispolitiek wees.

- Die uitsending van sport op 'n Sondag kan nie uitgesonder word asof daar 'n wesensonderskeid tussen 'n sportuitsending en die uitsending van 'n ander program is nie. Die aanvaarbaarheid van ' $n$ uitsending op 'n Sondag kan nie daaraan gemeet word of dit 'n sportuitsending is of nie. Indien ons wel 'n 
onderskeid wil maak, kan ons dit nie veel verder deurtrek as 'n onderskeid tussen godsdienstige en godsdienstig-opbouende uitsendings en ander uitsendings nie.

- Die inhoud van die uitsendings is wel belangrik, naamlik of dit godsdienstig, moreel of andersins afbrekend is. Die kerk het ' $n$ reg en 'n verantwoordelikheid om hom hieroor uit te spreek.

Uit bostaande is dit duidelik dat dit nie veel sou beteken indien die Kerk hom alleen oor sportuitsendings op 'n Sondag uitspreek nie. Die Kerk behoort egter 'n algemene beroep op instansies soos die SAUK doen ten opsigte van alle uitsendings op 'n Sondag. Dit is beter om 'n standpunt oor alle uitsendings op Sondag in te neem, en dit omvat die volgende:

- Die taak van die uitsaaiwese om ook op Sondae uitsendings te doen word erken, ook uitsendings wat die gebeure van die dag, insluitende sportbyeenkomste, dek.

- Aandag moet gegee word om so ver moontlik die programrooster en populêre uitsendings op Sondag so in te rig dat dit nie in kompetisie staan met die gebruiklike tye vir kerklike samekomste en godsdiensoefening nie.

- Programme moet so gekeur word dat dit nie afbreuk doen aan die gees van die Christelike Sondag nie, naamlik as 'n dag aan die Here gewy en 'n feesdag tot eer van die Here.

- Sportuitsendings op Sondag moet nie so 'n oorheersende plek inneem dat die indruk verkry word dat dit 'n sportdag in plaas van 'n dag vir die diens van die Here is nie.

- Die kerk aanvaar sy verantwoordelikheid om sy lidmate in sy prediking en kategese op te voed in die regte Sondagviering.

\section{Literatuurverwysings}

Calvyn, J [1545] 1981. Kategismus. Vertaal deur Simpson, H W. Silverton. (Potchefstroomse Teologiese Publikasies.)

-.- 1559. Institutio Christianae religionis.

Da Silva, A A 1966. Die Sondagbeskouing van Johannes Calvyn en prof dr Karl Barth. BD-skripsie, Universiteit van Pretoria.

Douma, J 1981. Etiek 111. Kampen: Kok.

Haitjema, Th L 1962. De Heidelbergse Catehechismus als klankbodem en inhoud van het actuele belijden onzer kerk. Wageningen: Veenman \& Zonen. 
Nederduitsch Hervormde Kerk van Afrika 1970. Agenda met bylaes vir die ses-envyftigste Algemene Kerkvergadering van die Nederduitsch Hervormde Kerk van Afrika. Pretoria.

Heyns, J A 1986. Teologiese Etiek 2/1. Pretoria: NG Kerkboekhandel.

Soe, N H 1965. Christliche Ethik. Dritte Auflage. München: Kaiser.

Van Wyk, J H 1986. Gesindheid en gestalte. Pretoria. NG Kerkboekhandel. 